\title{
AKTIVITAS PENGEMBANGAN KOMPETENSI SUMBER DAYA MANUSIA DALAM PENGELOLAAN PELAYANAN IBADAH HAJI
}

\author{
Tena Nissa Yusica ${ }^{1 *}$, Syamsuddin RS $^{2}$, Irfan Sanusi ${ }^{3}$ \\ 123 Jurusan Manajemen Dakwah, Fakultas Dakwah dan Komunikasi, UIN Sunan Gunung Djati, \\ Bandung \\ *Email :tenanissa@gmail.com
}

\begin{abstract}
The purpose of this study was to analyze the competency activities of training and education of employees in the Hajj service, the assessment of employee work in the Hajj service and employee career activities. The author uses the theory of Human Resource Management proposed by Garry Dessler. The results showed, First: Training and education carried out by the staff of the Section for Haij and Umrah Implementation of the method is to use the lecture system, internships, training in the classroom with the guidance of instructors. Second: Employee work assessments that include aspects of employee work assessment include positive actions, negative actions, attendance, discipline, loyalty, work performance, responsibility, obedience, bonesty, cooperation, initiative, and leadership and carried out in the office using the critical incident method, methods of goal management, methods of important events, and methods of field review. Third: the benchmark for determining employee careers must have good understanding, skills, knowledge, capacity and competence in terms of management of study. So that buman resources increase.
\end{abstract}

Keywords: Activity; Competency; Human Resources; Hajj Services.

\begin{abstract}
ABSTRAK
Tujuan penelitian ini untuk menganalisis aktivitas kompetensi pelatihan dan pendidikan karyawan dalam pelayanan ibadah haji, penilaian kerja karyawan dalam pelayanan ibadah haji dan aktivitas karir karyawan. Penulis menggunakan teori Manajemen Sumber Daya Manusia yang dikemukakan oleh Garry Dessler. Hasil penelitian menunjukan, Pertama: Pelatihan dan pendidikan dilakukan oleh Staf Seksi Penyelenggaraan Haji dan Umrah metodenya adalah dengan menggunakan sistem ceramah, magang, pelatihan dalam kelas dengan bimbingan instruktur. Kedua: Penilaian kerja karyawan yang mencakup aspek penilaian kerja karyawan meliputi perbuatan positif, perbuatan negatif, kehadiran, kedisiplinan, kesetiaan, prestasi kerja, tanggung jawab, ketaatan, kejujuran,
\end{abstract}


kerjasama, prakarsa, dan kepemimpinan dan dilakukan di dalam kantor dengan menggunakan metode kajadian kritis, metode manajemen tujuan, metode kejadian penting, dan metode tinjauan lapangan. Ketiga: yang menjadi tolak ukur penentuan karier karyawan harus memiliki pemahaman, keterampilan, ilmu pengetahuan, kapasitas dan kompetensi yang baik dalam hal manajemen perhajian. Sehingga sehingga sumber daya manusia yang meningkat.

Kata Kunci: Aktivitas; Kompetensi; Sumber Daya Manusia; Pelayanan Ibadah Haji.

\section{PENDAHULUAN}

Setiap instansi memerlukan sumber daya manusia yang memiliki kapasitas kompetensi yang berkualitas, akan tetapi terdapat kekurangan dalam pengelolaan pelayanan ibadah haji di Kantor Kementrian Agama Kabupaten Subang agar kapasitas kompetensi serta kualitas kinerja meningkat, hal ini disebabkan sumber daya manusia yang kurang profesional seperti pelaksanaan job description yang tidak sesuai dikarenakan kurang memahami fungsi dan tugas jabatan yang diembannya, pengelolaan pelayanan calon jemaah haji kurang maksimal, dengan meninjau permasalahan di atas maka perlu diadakan pengembangan sumber daya manusia agar kapasitas kompetensi serta kualitas kinerja meningkat.

Kegiatan pengembangan sumber daya manusia pernah dilaksanakan dan polanya pun sudah ada akan tetapi jarang diaplikasikan secara terus menerus, sehingga diperlukan pola pengembangan sumber daya manusia yang efektif dan efisien dalam hal pelayanan ibadah haji. Pengelolaan pelayanan ibadah haji akan lebih baik pada tahun berikutnya apabila dikelola oleh sumber daya manusia yang profesional, proporsional, serta memiliki kapasitas dan kompetensi yang berkualitas.

Padahal kompetensi mutlak dibutuhkan oleh sebuah organisasi atau lembaga apapun namanya jika lembaga tersebut menginginkan kemajuan. Kompetensi, talenta dan resiliensi dibutuhkan oleh sumber daya profesional dan unggul (Labola, 2019; Ramly, 2016). Damingun (2017) menyebut kompetensi merupakan kriteria efektif dan peformance yang superior dalam situasi pekerjaan. Kompetensi perlu dikembangkan pada sumber daya manusia dengan mempersiapkan lingkungan situasi yang menunjang (Efendi, 2015).

Penelitian Pengembangan Sumber Daya Manusia bukan hal baru, misalnya diteliti Priyono, Al Musadieq, dan Prasetya (2016) yang berjudul Pengembangan Sumber Daya Manusia melalui Pelatihan dalam Meningkatkan Kompetensi Tenaga Kerja Indonesia yang Bekerja ke Luar Negeri. Hasil penelitiannya menunjukkan bahwa terdapat banyak perubahan yang terjadi pada diri TKI pasca mengikuti pelatihan seperti meningkatnya pemahaman terhadap pekerjaan dan sikap kerja yang baik. 
Penelitian lain dilakukan oleh Azmy (2015) dengan judul Pengembangan Kompetensi Sumber Daya Manusia untuk Mencapai Career Ready Professional di Universitas Tanri Abeng. Hasil penelitian menunjukan bahwa pengembangan kompetensi SDM perlu dilakukan untuk mencapai tujuan organisasi.

Sedangkan variable lain yang berhubungan dengan penelitian dilakukan oleh Setiawan (2015) tentang Kepemimpinan Organisasi dalam Lembaga Islam. Hasil penelitiannya menunjukkan bahwa setiap individu menjadi sangat penting bagian dari organisasi yang menjunjung tinggi nilai-nilai budaya yang dikembangkan dari tahun ke tahun tahun, yang berakar pada nilai-nilai kuat yang akan melahirkan karyawan percaya komitmen yang kuat. Jika ini diabaikan itu akan menghasilkan lebih sedikit komitmen karayawan, motivasi dan tingkat kinerja karyawan yang tidak memuaskan, yang pada gilirannya akan merusak perusahaan itu sendiri.

Berdasarkan aturan, tentang pengelolaan ibadah haji diteliti oleh Fanham (2015) tentang Penyelenggaraan Ibadah Haji: Masalah Dan Penanganannya. Hasilnya adalah bahwa materi muatan yang perlu direvisi antara lain mengenai pembatasan pendaftar haji, organisasi penyelenggara, panitia penyelenggara, petugas haji, dan biaya penyelenggaraan ibadah haji.

Sementara Nidzam (2015) melakukan penelitan tentang haji dari sisi prosedur pendaftaran. Hasilnya menunjukkan bahwa proses rekayasa ulang serta rancangan baru prosedur pendaftaran haji lebih baik dari sistem lama terkait dengan beberapa aspek pelayanan dalam penyelenggaraan haji. Karenanya, hasil penelitian ini memiliki signifikansi penting terkait penyelenggaraan ibadah haji secara keseluruhan.

Penelitian lainnya dilakukan oleh Susilawati, Sarbini, dan Setiawan (2016), hasil penelitiannya adalah bahwa implementasi fungsi manajemen dalam pelayanan yang diberikan oleh KBIH Bustanul Wildan terhadap tingkat kualitas calon jamaah terdiri dari fungsi manajemen, yang terdiri dari perencanaa, pengorganisasian, pelaksanaan dan evaluasi.

Sedangkan penelitian ini berfokus pada pengembangan SDM dalam pengelolaan ibadah haji.

Dengan dilatar belakangi permasalahan di atas, yang berkaitan dengan pengembangan pola sumber daya manusia dalam aktivitas pelayanan ibadah haji (penelitian di Kantor Kementrian Agama Kabupaten Subang), maka muncul beberapa permasalahan,yaitu: 1) Bagaimana pengembangan kompetensi pelatihan dan pendidikan karyawan dalam pelayanan ibadah haji di Kantor Kementrian Agama Kabupaten Subang; 2) Bagaimana penilaian kerja kapasitas keompetensi karyawan setelah mengikuti pelatihan dan pendidikan karyawan dalam pelayanan ibadah haji di Kantor Kementrian Agama Kabupaten Subang; dan 3) Bagaimana aktivitas karier para staf Seksi Penyelenggaraan Haji dan 
Umroh di Kantor Kementrian Agama Kabupaten Subang.

Tujuan penelitian ini untuk menganalisis aktivitas kompetensi pelatihan dan pendidikan karyawan dalam pelayanan ibadah haji, penilaian kerja karyawan dalam pelayanan ibadah haji dan aktivitas karir karyawan di Kantor Kementrian Agama Kabupaten Subang. Penulis menggunakan teori Manajemen Sumber Daya Manusia yang dikemukakan oleh Garry Dessler. Penelitian ini merupakan penelitian deskriptif kualitatif dengan menggunakan metode deskriptif. Pengumpulan datanya menggunakan teknik observasi, wawancara dan studi dokumentasi. Analisis data dalam penelitian ini guna penafsiran logika yang dihubungkan dengan konteks jurusan menejemen dakwah.

\section{Landasan Teoritis}

Sumber daya dibutuhkan perusahaan atau organisasi tidak dapat dilihat sebagai bagian yang berdiri sendiri, tetapi sebagai satu kesatuan yang tangguh membentuk suatu sinergi.Sumber daya manusia harus dikelola dengan baik agar berjalan efektif dan efisien dengan menggunakan manajemen.

Management is a distinct process consisting of planning, organizing, actuating and controlling to determine and complish stated objectives by the use of buman being and other resource, artinya manajemen adalah suatu proses yang khas yang terdiri dari tindakan perencanaan, pengorganisasian, pengarahan, dan pengadilan yang dilakukan untuk menentukan serta mencapai sasaran yang telah ditentukan melalui proses pemanfaatan sumber daya manusia dan sumber sumber yang lain (Terry, 2001:3).

Sumber daya manusia adalah orang-orang yang ada dalam organisasi yang meberikan sumbangan pemikiran dan melakukan berbagai jenis pekerjaan dalam mencapai tujuan organisasi.Sumbangan yang dimaksud adalah pemikiran dan pekerjaan yang mereka lakukan diberbagai kegiatan dalam perusahaan. Dalam pengertian sumber daya manusia, yaitu diliputi bukanlah terbatas kepada tenaga ahli, tenaga pendidikan ataupun tenaga yang berpengalaman daja tetapi semua tenaga kerja yang digunakan perusahaan untuk mewujudkan tujuan-tujuannya (Sukirno, 2006:172).

Sementara manajemen sumber daya manusia pada dasarnya merupakan suatu kegiatan mengelola sumber daya manusia secara efektif dan efesien dalam mencapai tujuan bersama pada sebuah organisasi yang berfokus pada suksesnya organisasi.

Manajemen sumber daya manusia merupakan semua konsep dan teknik yang dibutuhkan untuk menangani aspek personalia atau sumber daya manusia dari sebuah posisi manajerial, seperti seleksi, pelatihan, pemberian imbalan, dan penilaian. (Dessler, 2000:2)

Unsur-unsur aktivitas pengembangan sumber daya manusia, meliputi: (a) pengembangan kapasitas kompetensi karyawan yaitu pelatihan dan pendidikan 
karyawan, (b) penilaian kerja karyawan, dan (c) mengelola karier karyawan (Dessler, 2000:267).

Dalam pengembangan kapasitas kompetensi karyawan diperlukan adanya pelatihan dan pendidikan. Pelatihan adalahproses mengajar keterampilan yang dibutuhkan karyawan baru untuk melakukan pekerjaan. Tujuan diadakannya pelatihan adalah pendekatan integrasi, dan berorientasi pada tujuan untuk menugaskan, melatih, menilai, dan memberikan penghargaan pada kinerja karyawan (Dessler, 2000:280).

Setelah karyawan diberikan pelatihan dan pendidikan maka pihak personalia dan pemimpin harus menilai kinerja karyawan tersebut. Pemimpin dan personalia menganalisis kayawan dengan adanya peningkatan kapasitas dan kompetensi karyawan atau tidak, penilaian tersebut berguna untuk menentukan karier atau pengelolaan karier karyawan.

Penilaian kerja berarti mengevaluasi kinerja karyawan saat ini dan dimasa lalu relatif terhadap standar prestasinya. Penilaian kinerja merupakan suatu proses organisasi dalam menilai kerja pegawai. Tujuan dilakukan penilaian untuk kerja secara umum adalah untuk memberikan feedback kepada pegawai dalam upaya memperbaiki tampilan kerjanya dan upaya meningkatkan produktivitas organisasi, dan secara khusus dilakukan dalam kaitannya dalam berbagai kebijaksanaan pegawai seperti untuk tujuan promosi, kenaikan gaji, pendidikan dan pelatihan, dan lain-lain.(Dessler, 2000:322)

Penilaian kerja karyawan akan mempengaruhi karier karyawan di masa yang akan datang, karna pemimpin dapat melihat peningkatan kapasitas kompetnsi karyawan sehingga layak untuk penaikan jabatan, peningkatan gaji, serta mendukung kesejahteraan karyawan apabila karyawan tersebut memiliki kapasitas kompetensi yang optimal.

Karier adalah posisi pekerjaan yang dimiliki seseorang selama bertahuntahun. Manajemen karier adalah proses untuk membuat karyawan dapat memahami dan mengembangan dengan lebih baik keahlian dan minat karier mereka, dan untuk memanfaatkn keahlian dan minat ini dengan cara yang paling efektif (Flippo, 1984:271).

Kantor Kementrian Agama Kabupaten Subang adalah lembaga pemerintahan yang mengelola kegiatan dakwah salah satunya dalam pengelolaan pelayanan ibadah haji. Ibadah haji merupakan rukun islam yang ke lima yang wajib dilaksanakan oleh umat Islammyang memenuhi kriteria istitha'ah antara lain mampu secara materi, fisik, dan mental(Depag RI, 1999:19-20).

Peningkatkan pembinaan, pelayanan, dan perlindungan terhadap jamaah haji diupayakan dalam penyempurnaan sistem dan manajemen penyelenggaraan, pelayanan ibadah haji.Oleh karna itu untuk menghasilkan pelayanan yang baik kepada jemaah haji maka sumber daya manusia yang ada harus dikembangkan 
dari segi kapasitas, kompetensi, keilmuan, pengalaman, dan lain-lain.

Berdasarkan pemaparan diatas dapat ditarik suatu kerangka pemikiran tentang pengembangan sumber daya manusia yang didalamnya meliputi: (1) pelatihan dan pendidikan untuk meningkatkan kapasitas kompetensi karyawan, (2) penilaian kerja kapasitas kompetensi karyawan, dan (3) mengelola karir karyawan.Dengan pengembangan di atas akan menghasilkan karyawan yang memiliki kapasitas dan kompetensi yang berkualitas, peningkatan kinerja yang profesional dan proporsional sehingga kecurangan, pemerasan, penyalahgunaan tugas, wewenang dan tanggung jawab dapat diminimalisir, upaya untuk meningkatkan pelayanan ibadah haji agar bisa memuaskan jemaah haji.

\section{HASIL DAN PEMBAHASAN}

Masyarakat di kabupaten Subang dalam hal pendaftaran calon jemaah haji dan umroh sangat meningkat dua kali lipat lebih banyak dari tahun-tahun sebelumnya. Oleh karena itu, instansi atau lembaga pemerintah yang menangani pengelolaan pelayanan ibadah haji harus sigap melayani masyarakat, serta sumber daya manusia yang ada di harapkan memiliki kapasitas kompetensi yang berkualitas agar pengelolaan berjalan efektif dan efisien juga dapat menjalankan tugas, wewenang, tanggung jawab dengan profesional dan proposional.

Namun, meskipun demikian apabila diperhatikan secara cermat maka akan di dapatkan gambaran aktivitas pengelolaan pelayanan ibadah haji yang kurang optimal, seperti: sumber daya manusia yang kurang maksimal dalam menjalankan pengelolaan pelayanan ibadah haji, fasilitas (sarana, prasarana) dalam pelayanan ibadah haji kurang memadai dan lain-lain.

Dengan memperhatikan fenomena diatas merupakan tantangan bagi kita untuk mengkaji kembali mengenai aktivitas pengembangan sumber daya manusia dalam pengelolaan pelayanan ibadah haji seperti: pelatihan dan pendidikan karyawan untuk meningkatkan kapasitas kualitas kompetensi kinerja karyawan, penilaian kerja karyawan sebagai tolak ukur kinerja, peningkatkan kesejahteraan, serta bahan acuan dalam pengelolaan karier, dan mengelola karier karyawan yakni penempatan jabatan seseorang yang mempengaruhi terhadap aktivitas pengelolaan pelayanan ibadah haji.

\section{Pengembangan Kompetensi Pelatihan dan Pendidikan Karyawan dalam Pelayanan Ibadah Haji}

Pengembangan sumber daya manusia dalam pengelolaan pelayanan ibadah haji yang dilakukan oleh seksi Haji dan Umrah Kantor Kementerian Agama Kabupaten Subang sebagai usaha untuk meningkatkan kualitas kinerja, kapasitas dan kompetensi, serta menjadikan sumber daya manusia yang professional dan proporsional agar pengelolaan pelayanan ibadah haji berjalan efektif dan efisien, adalah 
Seksi Penyelenggaraan Haji dan Umrah sudah mengikuti diklat perhajian baik tingkat provinsi atau nasional (pusat) yaitu dalam satu tahun mengirimkan dua orang petugas untuk mengikuti diklat tentang perhajian selama sepuluh hari. Berikut tabel pelatihan yang ikuti:

\section{Tabel 1}

Pelatihan dan Pendidikan Sumber Daya Manusia dalam Pengelolaan

\begin{tabular}{|c|c|c|}
\hline Nama Staf & $\begin{array}{l}\text { Tahun } \\
\text { Masuk }\end{array}$ & Jenis Pelatihan \\
\hline ImasRofikoh & 2004 & Pelatihan tatacara pendaftaran haji (2006) \\
\hline Balyanudin & 2008 & $\begin{array}{l}\text { Pelatihan Prajabatan } \\
\text { Pelatihan Bendahara } \\
\text { Pelatihanke arsipan } \\
\text { Pelatihan diklat haji }\end{array}$ \\
\hline NgujiMurtafi'ah & 2005 & Diklat teknis pelaksanaan penyelenggaraan haji (2008) \\
\hline NonoWarjono & 2005 & $\begin{array}{l}\text { Diklat SISKOHAT }(2006,2007,2008) \\
\text { Orientasi SISKOHAT }(2009,2010,2011) \\
\text { DiklatPetugas haji atau PPIH Arab Saudi }(2010)\end{array}$ \\
\hline ElinMarlina & 2005 & Pelatihan pelaksanaan pendaftaran haji \\
\hline Hj.IdaNuraida & 2004 & $\begin{array}{l}\text { Pelatihan Bendahara } \\
\text { Pelatihan Kearsipan }\end{array}$ \\
\hline Drs. H. Hasanudin & 2004 & Pelatihan pelaksanaan perhajian kearsipan \\
\hline AchmadHerdis & 2005 & Diklat perhajian \\
\hline H. Gugun T & 2005 & Diklat perhajian \\
\hline
\end{tabular}

Sumber: Seksi Haji dan Umrah Kantor Kementerian Agama Kabupaten Subang

Palayanan ibadah haji dibagi dalam tiga aspek, yaitu 1) Staff Penyelenggara Haji dan Umroh sebagai peserta dan Direktorat Pembinaan Haji Direktorat Jendral Penyelenggara Haji dan Umroh sebagai panitia. Pelatihan dan pendidikan yang diikuti oleh staff Seksi penyelenggaraan Haji dan Umroh ini dinamakan "ORIENTASI Peragaan Manasik Haji; 2) Staff Seksi Penyelenggaraan Haji dan Umroh sebagai peserta dan Kasubag TU atau Kepagawaian Kantor Kementrian Agama Kabupaten Subang sebagai panitia.Aktivitas ini dilaksanakan di dalam kantor dengan cara pihak Kasubag TU atau Kepegawaian yang mengundang pemateri luar yang ahli dibidang kesekretariatan atau pihak Kasubag TU dan kepegawaian sendiri yang langsung menjadi pemateri.Para staff mengikuti pelatihan dan pendidikan materinya mengenai administrasi seperti tatacara pembuatan surat menyurat, memo, biasanya pelatihan dan pendidikan ini diberikan kepada staff yang dalam tahap pembelajaran atau masa orientasi pegawai seperti penggunaan komputer, tertib administrasi, pengarsipan, dan dain lain-lain. Metode yang digunakan dalam pelatihan dan pendidikan ini adalah dengan menggunakan metode sistem ceramah, magang, pelatihan dalam kelas dengan bimbingan instruktur. Namun, aktivitas pelatihan dan pendidikan ini jarang dilaksanakan, paling tidak satu tahun satu kali pelaksanaannya; dan 3) Staff 
penyelenggaraan Haji dan Umroh sebagai panitia pelatihan dan pendidikan, sedangkan yang menjadi pesertanya adalah petugas haji (Karu, Karom, Pembimbing dan pengurus KBIH, petugas KUA Kecamatan) dab calon jeaah haji dalam pelaksanaan bimbingan manasik haji.Aktivitas pelatihan dan pendidikan ini dilaksanakan di wilayah Subang, yakni biasa dilaksanakan di Aula Kantor Kementrian Agama Kabupaten Subang dan asrama haji Subang, melipitia) Bimbingan calon haji. Bimbingan kepada calon jemaah haji dalam pelaksaaan bekerjasama dengan KUA, Penyuluh Agama, Dapartemen Kesehatan, Ali Ulama, Lembaga atau Ormas Islam seperti IPHI, KBIH, dan lembaga lainnya dan b) Pelatihan Ketua Regu (Karu), dan Ketua Rombongan (Karom)

Dari Segi Metode yang digunakan dalam pelatihan dan pendidikan ini adalah dengan menggunakan metode sistem ceramah, magang, pelatihan dalam kelas dengan bimbingan instruktur. Metode tersebut dilakukan untuk melatih dan mendidik karyawan dalam pelayanan ibadah haji (Wawancara dengan Ketua Kasi H.Munawir Sajali S.Ag M.Ag Staff Haji dan Umroh Kantor Kementrian Agama Kabupaten Subang)

\section{Penilaian Kerja Kapasitas Kompetensi Karyawan setelah Mengikuti Pelatihan dan Pendidikan Karyawan dalam Pelayanan Ibadah Haji}

Penilaian kerja karyawan dilakukan oleh kepegawaian atau Kasubag TU Kementrian Agama Kabupaten Subang.Penilaian kerja karyawan dilakukan oleh atasan langsung yang ditunjukan sebagaimana tersebut dalam Keputusan Mentri Agama No. 493 Tahun 2003 atau serendah-rendahnya eselon IV pada Inspektorat Jendral Dapertemen Agama.Dengan demikina penilaian kerja karyaan dilaksanakan di masing-masing unit. Seperti staff Seksi Penyelenggaraan Haji dan Umroh dinilai oleh Kasi Penyelenggara Haji dan Umroh, dicatat dalam buku Penilaian Prestasi Kerja Pegawai (PPKP).

Pelaksanaa penilaian kerja karyawan mencakup pada aspek siapa yang dinilai, apa saja yang dinilai, kapan waktu penilaian dilakukan, dimana tempat penilaia, mengapa harus dilakukan penilaian, mengapa harus melakukan penilaian dan bagaimana cara penilaian kerja karyawan yang terangkum dalam $5 \mathrm{~W}+1 \mathrm{H}$.

Hal yang di nilai adalah setiap sikap, tingkah laku dan perbuatan PNS yang menonjol, baik positif maupun negative, seperti: 1) perbuatan yang positif, seperti tindakan menyelamatkan kekayaan Negara dari perampokan atau bahaya kebakaran, prakarsa yang menimbulkan keuntungan bagi Negara,ide-ide yang bermanfaat dan dipublikasikan atau penulisan karya ilmiah atau buku-buku yang bermanfaat bagi insitusi atau PNS, dan lain-lain; dan 2) perbuatan yang negatif, seperti berkelahi,membuat tulisan yang merongrong kewibawaan pemerintah, menyalahgunakan wewenang, melakukan $\mathrm{KKN}$, malas bekerja, sering tidak masuk kantor, tidak bisa bekerjasama dan lain-lain.

Waktu pencatatan atau penilaian prestasi kerja karyawan dilakukan oleh 
pejabat penilai dalam kurun sewaktu-waktu, berkala dan waktu-waktu tertentu: yang dilakukan di dalam kantor, setiap ada kejadian penting seperti penyimpangan, sanksi, kegagalan,prestasi, dan lain-lain.Penilaian kerja karyawan ini digunakan sebagai bahan objektif, pertimbangan dalam pemberian penghargaan, sanksi,kenaikan jabatan, promosi, demosi, pemecatan, dan lainlain.

Adapun cara penilaian kerja karyawan dilakukan dengan menggunakan beberapa metode, yaitu: 1) metode kejadian kritis, 2) etode manajemen tujuan, 3) metode kejadian penting, dan 4) metode tinjauan lapangan.

Pengawasan penilaian kerja karyawan dilakukan sesuai hierarki atau structural yang ada yakni terangkum dalam gambar berikut:

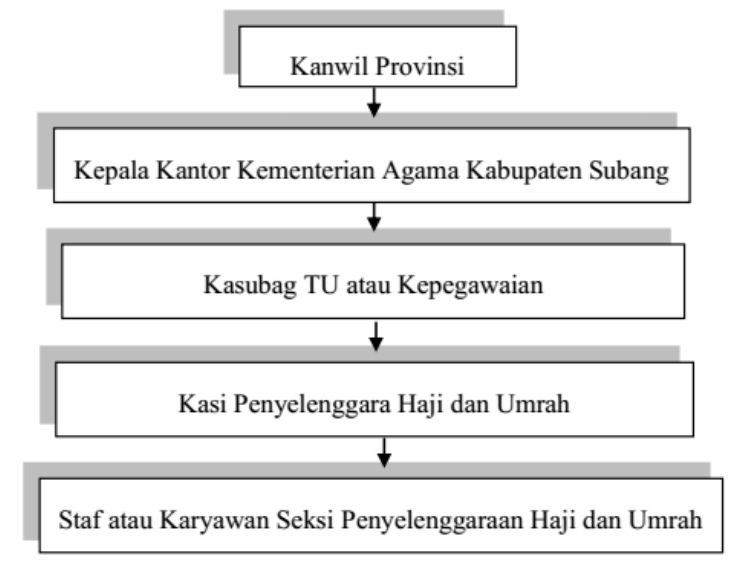

\section{Gambar 1}

Susunan Pengawasan Penilaian Kerja Karyawan

Sumber: Seksi Haji dan Umrah Kantor Kementerian Agama Kabupaten Subang

Evaluasi penilaian kerja karyawan dilakukan selama 2 (dua) minggu sekali yakni: 1) Setiap hari selasa yakni evaluasi yang dilakukan oleh seluruh pegawai dalam acara pembinaan karyawan dan 2) Setiap hari rabu yakni evaluasi dilakukan oleh kumpulan para kasi atau masing-masing unit untuk dilaporkan kepada kepala Kantor Kementerian Agama Kabupaten Subang.Dari Segi Penilaian Kerja Karyawan yang mencakup aspek perbuatan positif, perbuatan negatif, kehadiran, kedisiplinan, kesetiaan, prestasi kerja, tanggung jawab, ketaatan, kejujuran, kerjasama, dan kepemimpinan kepada seluruh karyawan yang akan memperbaiki kekurangan yang terjadi dalam pelayananan ibadah haji

\section{Aktivitas Karier Para Staff Seksi Penyelenggaraan Haji dan Umroh}

Perencanaan karier karyawan melihat pada aspek pendidikan, keterampilan, pengetahuan, keilmuan,prestasi karyawan, catatan penilaian kerja pegawai (PPKP) baik positif maupun negative. 
Pengorganisasian Karier karyawan disini kepala Kantor Kementerian Agama Kabupaten Subang yang menentukan naik turunnya jabatan seseorang, layak atau tidaknya karyawan menduduki sebuah jabatan bersumber dari informasi Kasubag TU atau kepegawaian yang memiliki data-data mengenai catatan penilaian prestasi kerja pegawai (PPKP)

Jadi penilaian kerja sangat berpungsi bagi atasan untuk menimbang, memperhatikan, sebagai tolak ukur penentuan karier karyawan, sehingga sumber daya manusia yang ada hasil dari penilaian objektif maka karier yang didudukinya sesuai dengan bakat, minat, keterampilan, keahlian yang dimilikinya menghasilkan sumber daya manusia yang memiliki kapasitas kompetensi yang berkualitas serta professional dan proporsional dalam menjalankan tugasnya secara efektif dan efisien. Apabila penentuan jabatan atau karier sesuai dengan penilaian prestasi kerja pegawai yang objektif maka akan menghindarkan dari perbuatan KKN.

Pelaksanaan mengelola karier karyawan dilakukan dengan cara adanya rotasi pegawai, demosi, dan promosi jabatan yang dilaksanakan maksimal 3 (tiga) tahun sekali. Namun hal ini bias berubah yakni disesuaikan dengan kebutuhan kinerja, yakni apabila seorang karyawan dalam menduduki jabatannya ternyata hasil penilaian, pengawasan, dan evaluasi kinerjanya tidak baik atau membuat kerugian, berperilaku negative, melakukan KKN, maka kurang dari 3 (tiga) tahun pun langsung diberi sanksi baik berupa penurunan jabatan, skorsing, atau dipecat sekalipun, serta mempersiapkan promosi jabatan bagi karyawan lain yang memenuhi syarat untuk mengisi jabatan yang kosong.

Bagi promosi Kasi Penyelenggaraan Haji dan Umrah yang paling penting adalah memiliki pemahaman, keterampilan, ilmu pengetahuan, kapasitas dan kompetensi yang baik dalam hal manajemen perhajian.Selain hal di atas dilakukan pula pendekatan-pendekatan pengembanan karier karyawan yakni berupa pelatihan dan pendidikan yang dilaksanakan di Balai Diklat tingkat Provinsi.Pengawasandilakukan sesuai dengan hierarki atau structural yang ada yakni terangkum dalam gambar berikut:

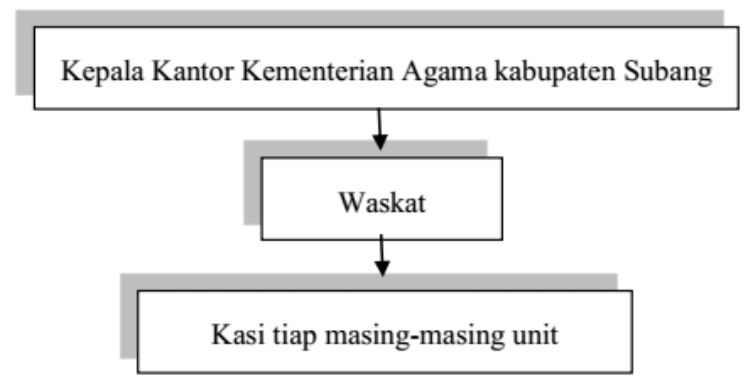

Sumber: Seksi Haji dan Umrah Kantor Kementerian Agama Kabupaten Subang 


\section{Gambar 2}

Struktur Pengawasan Karier Karyawan

Evaluasi ini dilakukan oleh Kepala Kantor Kementerian Agama Kabupaten Subang dilaksanakan setiap hari rabu, mengadakan evaluasi bersamakasi masing-masing unit. Selain itu juga terdapat evaluasi dari pihak intern yakni Direktorat Jenderal Nasional minimal 1 (satu) tahun sekali. Pengelolaan pelayanan ibadah haji dilakukan oleh staf yang telah kompeten dibidang perhajian agar kepuasan masyarakat atau calon jamaah haji dapat diutamakan.Adapun kegiatan pengelolaan pelayanan ibadah haji mencakup aspek pelayanan pra ibadah haji,pelayanan operasional haji (pelaksanaan haji), dan pelayanan pasca ibadah haji, dapat dilihat dalam gambar berikut:
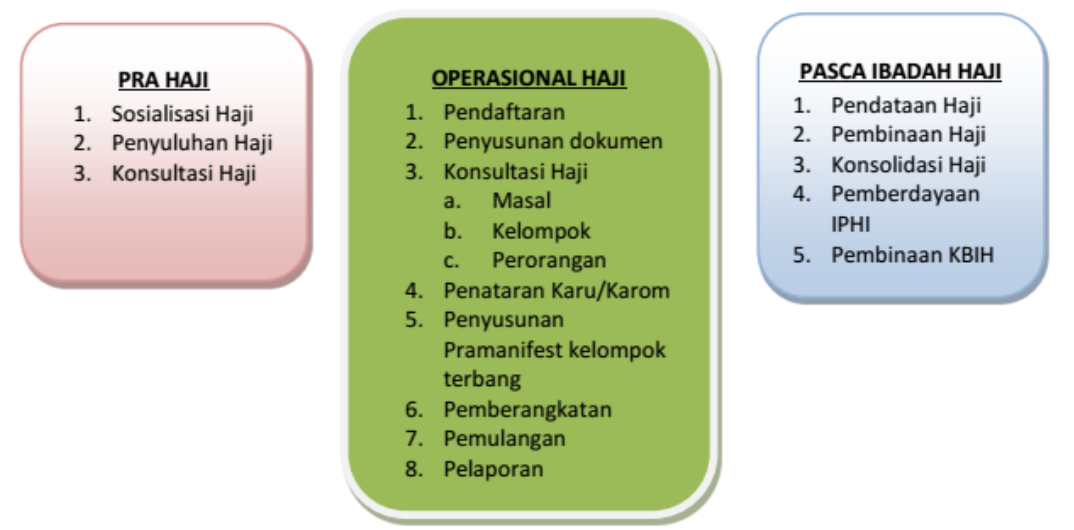

Sumber: Seksi Haji dan Umrah Kantor Kementerian Agama Kabupaten Subang

Gambar 2

Struktur Pengelolaan Pelayanan Ibadah Haji

Staf seksi Penyelenggara Haji dan Umrah kekurangan tenaga atau stafsehingga pekerjaan banyak sedangkan pelaksana atau sumber daya manusia sedikit, solusi yang diberikan adalah seharusnya ditambahkan staf musiman sebanyak 5-10 orang yakni sekitar 5 bulan sebelum pemberangkatan ibadah haji. Ketidak teraturan job descriptions yang ada artinya kelalaian terhadap tugas nya dengan yang dilaksanakan dilapangan, solusinya dibutuhkan kerjasama serta penegasan terhadap tugas dan tanggungjawab apabila melakukan kelalaian diharapkan diberikan sanksi tegas dari pimpinan.

Kasi Seksi Penyelenggaraan Haji dan Umrah adalah bukanyang berlatar belakang dari bagian staf Seksi Penyelenggaraan Haji dan Umrah, tetapi dari bagian umum unit lain, hal ini mengakibatkan kurangnya wibawa seorang pemimpin sehingga dalam program kerja atau kegiatan sehari-hari khususnya saat 
mendekati pelaksanaan pemberangkatan calon jamaan haji pemimpin kurang ikut berpartisipasi aktif dalam kegiatan tersebut. Sehingga dibebankan kepada staf. Solusinya, diharapkan Kasi Penyelenggaraan Haji dan Umrah sendiri yang sudah memenuhi syarat sebagai Kasi, maka wibawa, tugas, wewenang, tanggung jawab sudah dipahami minimal memiliki pengalaman selama menjadi staf yang kompeten.

Fasilitas pelayanan ibadah haji perlu ditambah yakni sesuai dengan program jangka panjang yaitu melakukan pelayanan ibadah haji dalam satu atap mulai dari menyediakan Bank sebagai tempa tabung haji, dinas kesehatan untuk mengecek golongan darah, kesehatan, dan lain-lain sehingga calon jemaah haji tidak bolak-balik dengan jarak yang cukup jauh apabila dilakukan satu atap maka akan mempermudah pendaftaran, calon jemaah haji merasa nyaman, dan tidak banyak membuang waktu untuk bolak-balik pergi ke Bank, tempat kesehatan, dan lain-lain.

Sebenarnya dalam aktivitas karir karyawan yang paling penting adalah memiliki pemahaman, keterampilan, ilmu pengetahuan, kapasitas dan kompetensi yang baik dalam hal manajemen perhajian untuk menjadi tolak ukur penentuan karier karyawan, sehingga sumber daya manusia yang ada hasil dari penilaian objektif maka karier yang didudukinya sesuai dengan bakat, minat, keterampilan, keahlian yang dimilikinya menghasilkan sumber daya manusia yang memiliki kapasitas kompetensi yang berkualitas serta professional dan proporsional dalam menjalankan tugasnya secara efektif dan efisien.

\section{PENUTUP}

Berdasarkan data hasil penelitian, dapat disimpulkan 1) Aktivitas Kompetensi Pelatihan dan Pendidikan Karyawan dalam pelayanan ibadah haji yang dilakukan oleh Staf Seksi Penyelenggaraan Haji dan Umrah sebagai panitia pelatihan dan pendidikan, sedangkan yang menjadi pesertanya adalah petugas haji (Karu, Karom,Pembimbing atau Pengurus KBIH, Petugas KUA Kecamatan) dan calon jemaah haji dalam pelaksanaan bimbingan manasik haji. Metode yang digunakan dalam pelatihan dan pendidikan ini adalah dengan menggunakan metode sistem ceramah, magang, pelatihan dalam kelas dengan bimbingan instruktur.

Namun, aktivitas pelatihan dan pendidikan ini jarang dilaksanakan, paling tidak satu tahun satu kali pelaksanaannya; 2) Penilaian Kerja Karyawan yang mencakup aspek penilaian kerja karyawan meliputi perbuatan positif, perbuatan negatif, kehadiran, kedisiplinan, kesetiaan, prestasi kerja, tanggung jawab, ketaatan, kejujuran, kerjasama, prakarsa, dan kepemimpinan.Penilaian kerja karyawan dilakukan di dalam kantor dengan menggunakan metode kajadian kritis, metode manajemen tujuan, metode kejadian penting, dan metode tinjauan 
lapangan; dan 3) Aktivitas Karier Karyawan dalam penilaian kerja sangat berpungsi bagi atasan untuk menimbang, memperhatikan, sebagai tolak ukur penentuan karier karyawan, sehingga sumber daya manusia yang meningkat. Hasil dari penilaian objektif maka karier yang didudukinya sesuai dengan bakat, minat, keterampilan, keahlian yang dimilikinya menghasilkan sumber daya manusia yang memiliki kapasitas kompetensi yang berkualitas serta professional dan proporsional dalam menjalankan tugasnya secara efektif dan efisien.

Adapun saran yang ingin sampaikan yakni instansi agar lebih memfokuskan lagi kajiannya kepada: 1) Aktivitas pengembangan kompetensi sumber daya manusia dalampengelolaan pelayanan ibadah haji yang lebih komrehensif, optimal dan lebih meningkatkan kegiatan pelatihan dan pendidikan karyawan; 2) Peningkatan aktivitas pelayanan ibadah haji yang akan berguna bagi masyarakat atau calon jemaah haji; dan 3) Kurang lengkapnya arsif mengenai profil Kantor Kementerian Agama Kabupaten Subang.

\section{DAFTAR PUSTAKA}

Azmy, A. (2015) Pengembangan Kompetensi Sumber Daya Manusia untuk Mencapai Career Ready Professional di Universitas Tanri Abeng, Jurnal Binus Business Review 6 (2): 220-232.

Damingun .(2017). Pengembangan Sumber Daya Manusia Berbasis Kompetensi. Jurnal Ekonomi dan Manajemen, 11(2),245-252.

Depag RI . 2008. Undang-undang Republik Indonesia Nomor 13 Tabun 2006 Tentang Penyelenggaraan Ibadah haji. Jakarta: Depag RI.

Depag RI.(1999).Undang-undang Republik Indonesia Nomor 17 Tabun 1999 Tentang Penyelenggaraan Ibadah haji. Jakarta : Depag RI.

Dessler, G. (2007).Manajemen Sumber Daya Manusia Jilid 2. Jakarta : PT. Indeks

Dessler, G. (2006). Manajemen Sumber Daya Manusia Jilid 1. Jakarta : PT. Indeks

Dirjen PHU Depag RI .(2007). Pola Penyuluhan Haji. Jakarta : Depag RI

Dirjen PHU Depag RI. (2007). Perspektif KUA Dalam Pelayanan Haji. Jakarta : Depag RI

Dirjen PHU Depag RI. (2007). Pola Pembinaan Jemaah Haji. Jakarta : Depag RI Flippo, E.B. (1984). Manajemen Personalia. Jakarta : Erlangga

Efendi, N. (2015). Pengembangan Sumberdaya Manusia Berbasis Kompetensi di Kantor Pemerintah Kota Bandar Lampung. Mimbar, 31(1), 1-10.

Fanham, A.M. (2015) Penyelenggaraan Ibadah Haji, Masalah dan Penanganannya, Jurnal Kajian; Menjembatani Teori dan Persoalan dalam Perumususan Kebijakan, 20 (3): 201-2018.

Hariandja,M.T.E. (2009).Manajemen Sumber Daya Manusia: Pengadaan, Pengembangan, Pengkompensasian, dan Peningkatan Produktivitas Pegawai. Jakarta 
T. N Yusica

Labola, Y.A.(2019). Konsep Pengembangan Sumber Daya Manusia Berbasis Kompetensi, Bakat dan Ketahanan dalam Organisasi. JURNAL MANAJEMEN \& KEWIRAUSAHAAN, 7(1), 28-35.

Nidzam, A. (2015) Efektivitas Prosedur Pendaftaran Haji melalui Rakayasa Ulang Proses Bisnis, Penamas; Jurnal Penelitian Keagamaan dan Kemasyarakatan, 28 (3): 351-532.

Priyono, A.H., Al Musadieq, M., Prasetya, A. (2016) Pengembangan Sumber Daya Manusia Melalui Pelatihan dalam Meningkatkan Kompetensi Tenaga Kerja Indonesia yang Bekerja Ke Luar Negeri, Jurnal Administrasi Bisnis Universitas Brawijaya 33 (1): 43-51.

Ramly, A.T. (2016). Pengembangan Sumber Daya Manusia yang Unggul

Berbasis Pumping HR( Model Evaluasi Program di IPB University). Jurnal Manajemen, 7(2), 138 - 151.

Setiawan, A.I., (2015) Budaya Organisasi dalam Lembaga Islam, Jurnal Anida (Aktualisasi Nuansa Ilmu Dakwah), 14 (2): 341-355.

Susilawati, I., Sarbini, A., dan Setiawan, A.I. (2016) Implementasi Fungsi Manajemen dalam Pelayanan Bimbingan Manasik Haji di Kelompok Bimbingan Ibadah Haji, Tadhbir: Jurnal Manajemen Dakwah, 1 (2): 190-206.

Tim Penyusun. (2018). Panduan Penyusunan Skripsi Dakwah dan Komunikasi. Bandung: Fakultas Dakwah dan Komunikasi Universitas Islam Negeri Sunan Gunung Djati Bandung.

Terry, G.R. \& Rue, L.W. (2008). Dasar-dasar Manajemen. Jakarta : PT. Bumi Aksara. 